\title{
Riparian forest structure, vegetation cover and flood events in the Piave River
}

\author{
L. Picco ${ }^{1}$, L. Mao ${ }^{2}$, E. Rigon ${ }^{1}$, J. Moretto ${ }^{1}$, D. Ravazzolo ${ }^{1}$, \\ F. Delai ${ }^{1} \&$ M. A. Lenzi ${ }^{1}$ \\ ${ }^{1}$ Department of Land and Agroforest Environment, \\ University of Padova, Italy \\ ${ }^{2}$ Department of Ecosystems and Environment, \\ Pontificia Universidad Catolica de Chile, Santiago, Chile
}

\begin{abstract}
Until very recently, rivers have been considered as the result of the interaction between water and sediments, thus simplifying this very complex system. In doing so, one important component was missed. This is vegetation, namely trees growing on banks, floodplains, and bars/islands. The pattern of riparian vegetation in gravel bed rivers depends on the climate, hydrological regime, floods, sediment transport and the morphological settings of the river. Also, the marked spatial variability of density, height, species diversity, age, and rates of growth reflects the very complex nature of bed colonization, the strong influence of sequences and magnitude of floods, and the feedbacks between morphology, vegetation and hydraulics. Furthermore, a wide array of human impacts acting at either the basin or river network scales can influence substantially the morphodynamics and thus the characteristics, types and distribution of vegetation within the river corridor. The aim of the work is to analyze the relationship between the vegetation structure and the morphological characteristics of two sub-reaches of the Piave river which suffered both floods and intense and multiple human impacts especially due to dam building and inchannel gravel mining. Six cross sections were surveyed and vegetation, soil variables and sediment deposited were measured on 214 plots, (4 x $4 \mathrm{~m}$ each one and $10 \mathrm{~m}$ spaced). Each vegetation plot were recognized on a recent aerial photo (2009) and its ages were calculated performing both a multi-temporal analysis of older photos (1960, 70, 80, 91, 99, 2006 and 2009) and a dendro-chronological
\end{abstract}


analysis. The Piave River shows a complex pattern of vegetation distribution along the cross-sections with no clear relationship between the elevation and the plant communities. However later successional plant communities cover older surfaces and the thickness of the sand layer helps explaining differences in areas dominated by different species (e.g. Salix alba and Salix eleagnos).

Keywords: Italy, riparian forest, floods, vegetation cover, gravel bed rivers.

\section{Introduction}

The role of vegetation in mediating the morphodynamics of wide river systems is very important because the type and size of riparian vegetation play a crucial role in increasing bank strength against erosion $[1,2]$, and thus influencing fluvial style. The significant impact of vegetation growing on bars and floodplains on channel morphology has been increasingly verified in the field [1, 3, 4], numerically (Murray and Paola, [5]) as well as experimentally (Tal and Paola, [6]). These studies have begun to directly show the influence of riparian vegetation in stabilizing banks, increasing mean channel depths, significantly reducing the braiding index and increasing the ecological value of the riverine area. The pattern of riparian vegetation in gravel bed rivers depends on the climate, hydrological regime, and the morphological settings of the river. Also, the marked spatial variability of density, height, species diversity, age, and rates of growth reflects the very complex nature of bed colonization, the strong influence of sequences and magnitude of floods, and the feedbacks between morphology, vegetation and hydraulics [7-10]. In fact, the distribution of riparian species within the river corridor is usually related to certain hydrogeomorphic conditions that shaped the physical habitat. This is because the distributional pattern is controlled by the tolerance of a species for specific disturbance regimes $[7,11]$. However, a wide array of human impacts acting at either the basin or river network scales can influence substantially the morphodynamics and thus the characteristics, types and distribution of vegetation within the river corridor (Hupp and Rinaldi [12]). A river reach disturbed by a series of human impacts usually reacts adjusting its morphological pattern to changing liquid and sediment input conditions [13-15]. However, little evidence on vegetation patterns in altered and rapidly changing river systems are generally lacking in the literature.

The aim of the contribution is assess the vegetation types and distribution patterns in an Italian gravel-bed river (the Piave River) suffering from various degrees of human pressure and disturbances.

\section{Material and methods}

The Piave River basin (drainage area $4500 \mathrm{~km}^{2}$ ) lies in the eastern Italian Alps, and the main channel flows south for $220 \mathrm{~km}$ from its headwaters to the outlet in the Adriatic Sea, at the northeast of Venice. The climate is temperate-humid with an average annual precipitation of about $1350 \mathrm{~mm}$. Two 1-km long study reaches have been selected in the middle portion of the river course (drainage area 
$3180 \mathrm{~km}^{2}$ at the Busche dam (Figure 1)). The morphology of the river in the study reaches is dominated by braided and wandering channel patterns, the slope is around $0.45 \%$, and the $\mathrm{D}_{50}$ ranges between 20 and $50 \mathrm{~mm}$.
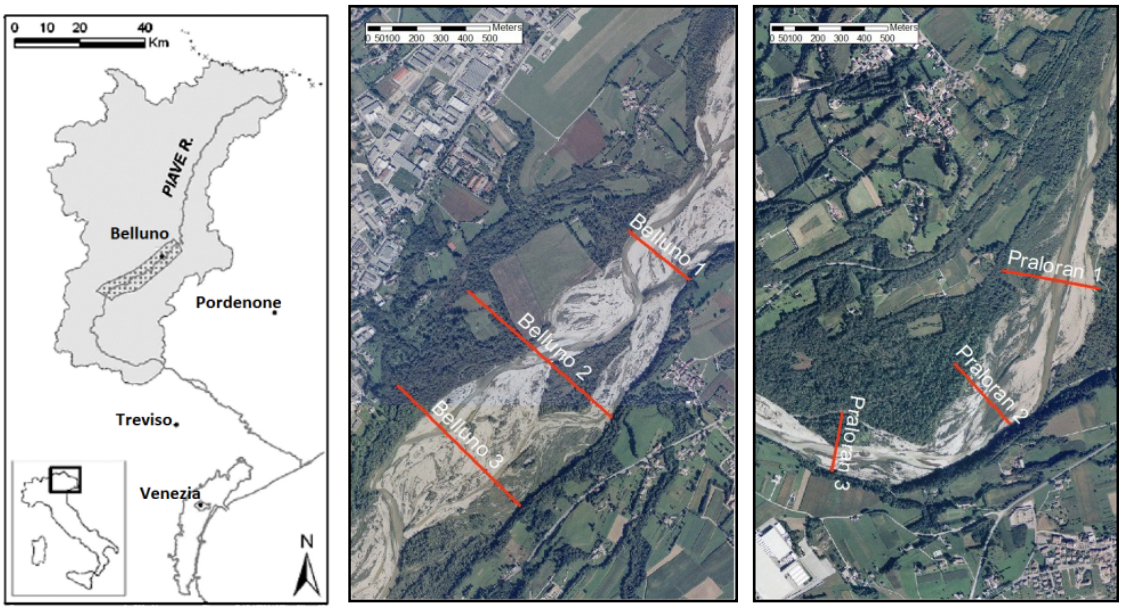

Figure 1: Location and aerial photo of the two analyzed reaches in the Piave River basin (Belluno reach on the left and Praloran reach on the right).

The Piave River has suffered intense and multiple human impacts, which altered the basin and the river channel. After centuries of impacts at the basin scale (mostly phases of deforestation and forestation), flows have been regulated for irrigation and hydroelectric power generation after the 1930. Up to the 1950s, dams were built in many parts of the drainage basin, intercepting sediments from more than $50 \%$ of the drainage area (Comiti et al. [15]). Also, between the $1960 \mathrm{~s}$ and 1990s, intense gravel mining was carried out in the main channel and in its main tributaries. Finally, effective erosion and torrent control works started in the upper basin in the 1930s [9, 16-19].

Six cross-sections (Fig. 1) were surveyed in 2010, and vegetation and soil variables were measured on $4 \times 4 \mathrm{~m}$ plots spaced $10 \mathrm{~m}$ one to another. In these selected plots, various vegetation and soil properties have been measured. As to the vegetation properties, the canopy cover (\%) was estimated and the forest community type was identified based on the presence and abundance of arboreal species. Each tree with a diameter $>5 \mathrm{~cm}$ was identified and its diameter, height, and canopy size was measured. Furthermore, on each plot, the thickness of fine layer was measured digging a scour, and the grain size distribution of coarse sediments was calculated from the measure of b-axes of at least 30 coarse elements. The nature of the morphological units where the plots lied was characterized and classified as channels, nude bars, high bars, vegetated bars, islands and floodplains $[3,4,20]$. 
In order to establish the persistence of each vegetation community as identified in the field, a multitemporal analysis was performed using aerial photos of the same areas dating 1960, 1970, 1980, 1991, 1999, 2006, and 2009. Each vegetation plot was recognized on the most recent aerial photo (2009) and its age was calculated comparing the vegetation characteristics on previous aerial photos, and from dendro-chronological analysis carried out in laboratory $[3,4]$.

\section{Results and discussion}

Overall, 214 plots have been surveyed along the 6 cross sections (Figure 2). A preliminary analysis reveals that communities typical of both highly dynamic (active and high bars) and stable (floodplains) units lie on surfaces with different age but at relatively similar elevation (Figure 3). Interestingly, the thickness of the sand layer helps explaining differences in areas dominated by different species (e.g. Salix alba and Salix eleagnos). Overall, the Piave River shows a complex pattern of vegetation distribution along the cross-sections, with no clear relationship between the elevation and the plant communities. This is contrasting with the typical plant species distributional patterns dependent on specific fluvial landforms and processes which has been identified in less disturbed river systems [7, 11, 21-23]. It is believed that the typical vegetation-landform is not respected in the study river due to its complex history of channel adjustments. Indeed, a comprehensive study carried out using historical maps, aerial photos, repeated topographic measurements, and geomorphological surveys revealed that the river underwent a strong narrowing during the twentieth century with an associated shift from a dominant braided pattern to a wandering morphology (Comiti et al. [15]). Large areas of the former active channel were colonized by riparian forests, both as islands and as marginal woodlands. The ceasing of gravel extraction in the late 1990s seems to have determined a reversal in the evolutionary trend, with evidence of vegetation erosion/channel widening (Comiti et al. [15]). This complex series of planimetric and vertical adjustments, and especially the recent active channel widening tendency may explain why "mature" patches lie at elevations similar to areas covered with the most pioneer plant communities (Picco et al. [24]).

Even if vegetation types seems not related to the elevation nor the age or morphological units, figure 4 reveals interesting differences in persistence and elevation between different morphological units. In fact, even if islands, floodplains and vegetated bars lie at relatively similar elevation, these morphological units are characterized by significantly different ages. Also, despite the fact that the sand layer thickness is higher on islands and floodplains, which are the older surfaces, the islands are much younger than floodplain surfaces (Figure 4). This is in agreement with the fact that there is a significant 
Monitoring, Simulation, Prevention and Remediation of Dense and Debris Flows IV 141

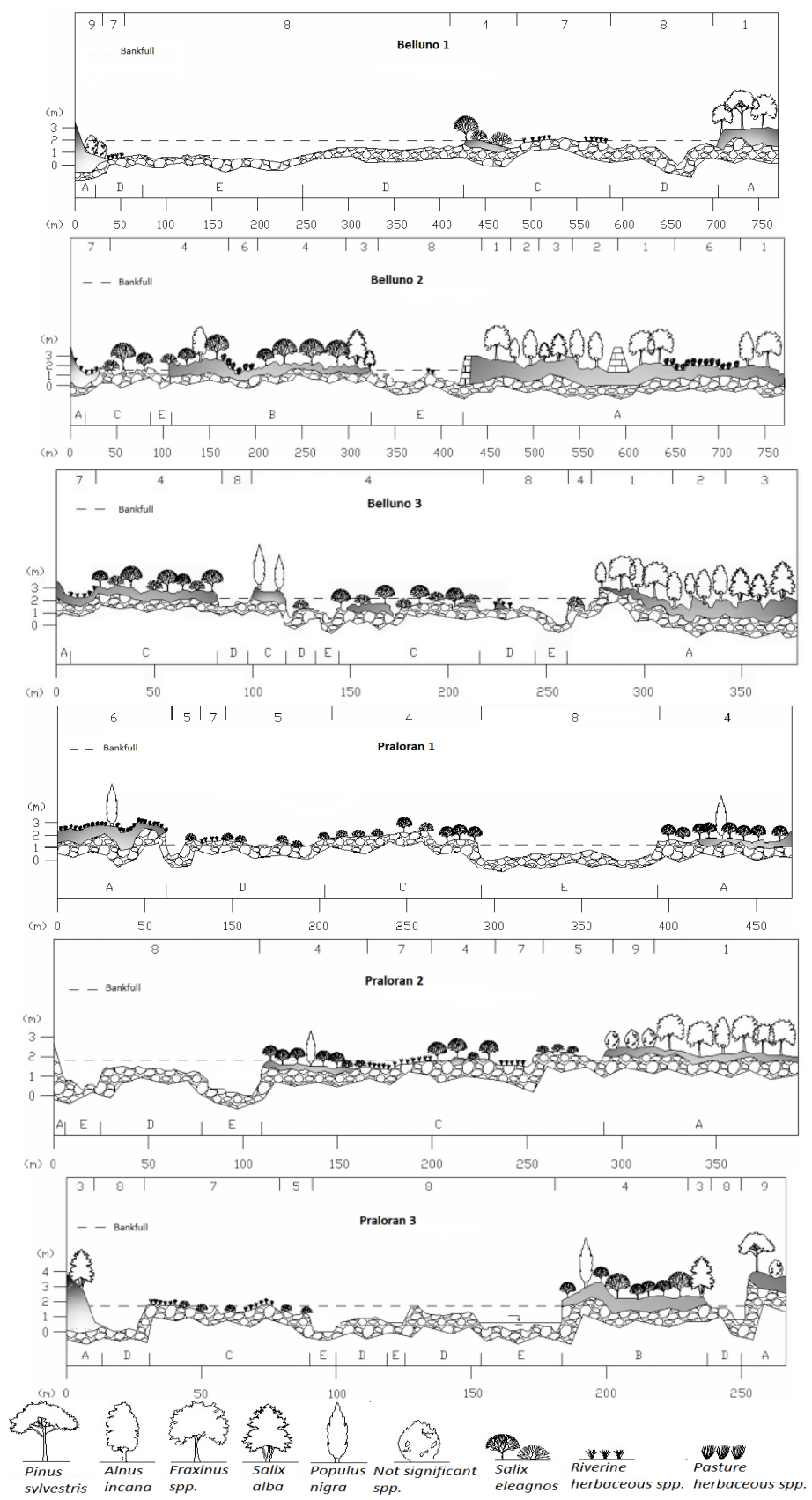

Figure 2: Vegetation characteristics, morphological units and soil properties along the cross sections located in the Belluno and Praloran reaches. 

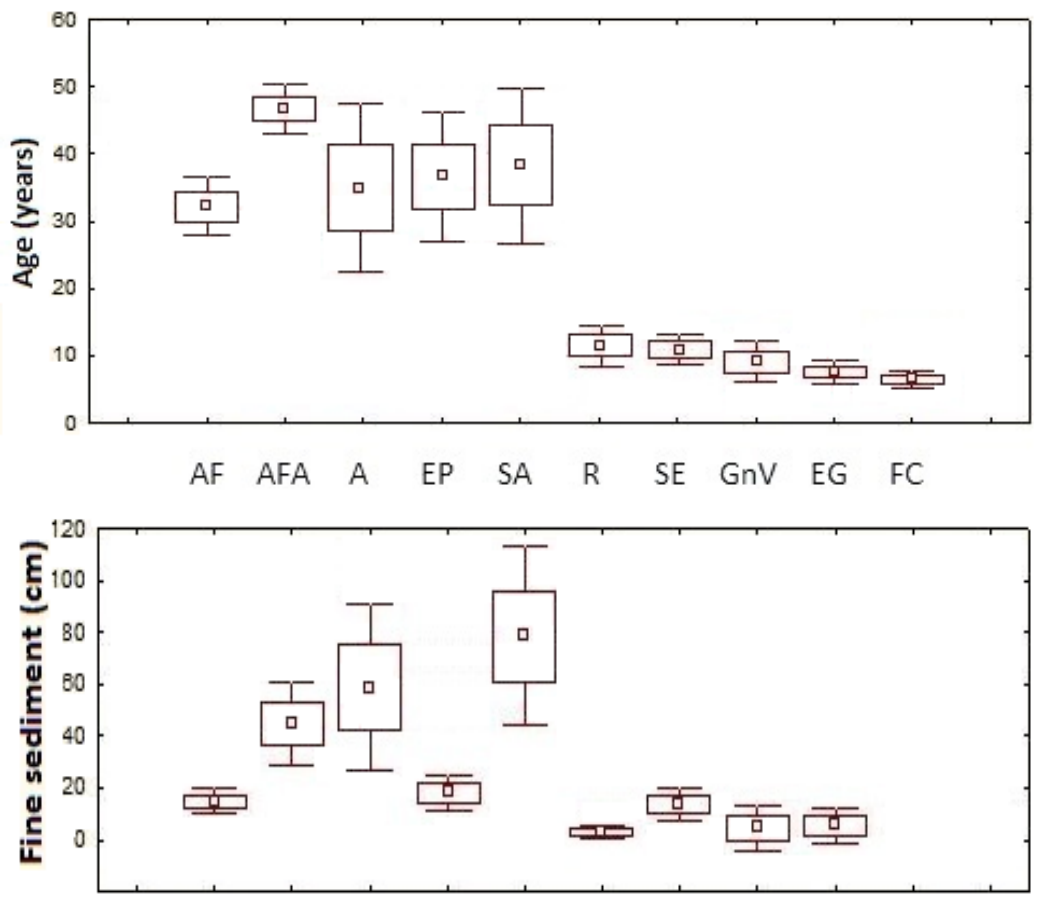

\section{AF AFA A EP SA $R$ SE GnV EG}

Figure 3: Ranges of age, elevation and thickness of fine sediments for the vegetation types growing in the Piave River (AF: Acer-Fraxinus; AFA: Acer-Fraxinuswith Alnusincana; A: Alnus incana; EP: Uncovered areas; SA: Salix alba; R: Areas with regeneration; SE: Salix eleagnos; GnV: No vegetation; EG: In-channel herbaceous; FC: Flowing channel).

difference in species dominating on islands and floodplains (Table 1), and suggests that their dynamics and formation processes are different. In fact, it is likely that in the Piave River islands are generated by processes of vegetation growth and surface aggradation (building islands) rather than from floodplain dissection. Building islands result from the progressive development of a vegetation cover and accumulation of fine sediment around sprouting threes lying on bars (Gurnell et al. [25]). In contrast, because floodplain dissection islands are created during major flood events capable of dissecting portion of floodplains, they usually have a more tabular cross-profile, and a relatively even tree age structure and age (Gurnell et al. [25]).

The fact that most of islands have pioneering origin has to the related to the recent 20-years phase of active channel widening, which allows both large wood recruitment from bank erosion (necessary for creating the pioneering cores) and chances for the building islands to resist the erosive force of ordinary floods. 
Interestingly, Figure 4 also shows that islands persist on the same area for 15 to 20 years, which is remarkably similarly to what found in the other gravel-bed rivers (Gurnell and Petts [11]; Zanoni et al. [26]).

Table 1: Differences in species dominating on islands and floodplains.

\begin{tabular}{|c|c|c|}
\hline Species & Island & Floodplain \\
\hline Acer campestre & $\mathrm{x}$ & $\mathrm{x}$ \\
\hline Acer pseudoplatanus & $\mathrm{x}$ & \\
\hline Alnus glutinosa & $\mathrm{x}$ & \\
\hline Alnus incana & $\mathrm{x}$ & \\
\hline Amorpha fruticosa & $\mathrm{x}$ & $\mathrm{x}$ \\
\hline Buddleja davidii & $\mathrm{x}$ & $\mathrm{x}$ \\
\hline Carpinus betulus & $\mathrm{x}$ & $\mathrm{x}$ \\
\hline Cornus mas & $\mathrm{x}$ & \\
\hline Cornus sanguinea & $\mathrm{x}$ & \\
\hline Corylus avellana & $\mathrm{x}$ & $\mathrm{x}$ \\
\hline Euonymus europaeus & $\mathrm{x}$ & \\
\hline Frangula alnus & $\mathrm{x}$ & \\
\hline Fraxinus angustifolia & $\mathrm{x}$ & \\
\hline Fraxinus excelsior & $\mathrm{x}$ & $\mathrm{x}$ \\
\hline Fraxinus ornus & $\mathrm{x}$ & $\mathrm{x}$ \\
\hline Juglans nigra & $\mathrm{x}$ & \\
\hline Ligustrum vulgare & & $\mathrm{x}$ \\
\hline Ostrya carpinifolia & & $\mathrm{x}$ \\
\hline Picea abies & $\mathrm{x}$ & \\
\hline Pinus sylvestris & $\mathrm{x}$ & \\
\hline Platanus acerifolia & $\mathrm{x}$ & \\
\hline Populus alba & $\mathrm{x}$ & $\mathrm{x}$ \\
\hline Populus nigra & $\mathrm{x}$ & $\mathrm{x}$ \\
\hline Prunus domestica & $\mathrm{x}$ & \\
\hline Robinia pseudoacacia & $\mathrm{x}$ & \\
\hline Salix alba & $\mathrm{x}$ & $\mathrm{x}$ \\
\hline Salix daphnoides & $\mathrm{x}$ & $\mathrm{x}$ \\
\hline Salix eleagnos & $\mathrm{x}$ & $\mathrm{x}$ \\
\hline Salix glaucosericea & & $\mathrm{x}$ \\
\hline Salix purpurea & $\mathrm{x}$ & $\mathrm{x}$ \\
\hline Salix triandra & $\mathrm{x}$ & $\mathrm{x}$ \\
\hline Tilia cordata & $\mathrm{x}$ & \\
\hline
\end{tabular}



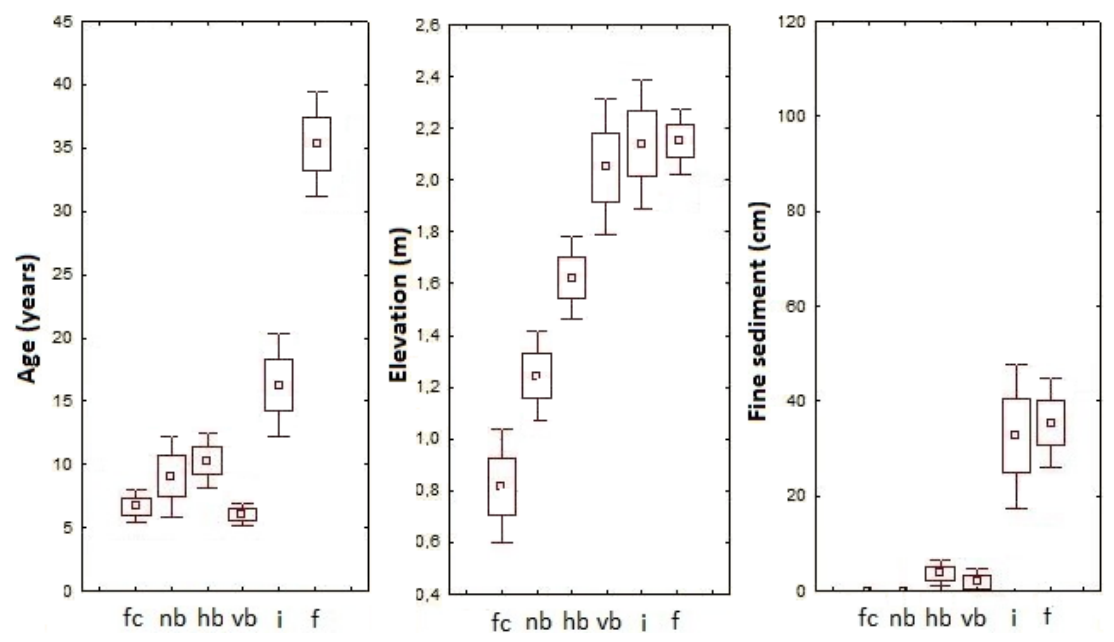

Figure 4: Ranges of age, elevation and thickness of fine sediments on plots belonging to different geomorphic units (fc: Flowing channel; nb: Nude bar; hb: High bar; vb: vegetated bar; i: Island; f: Floodplain).

\section{Final remarks}

Riparian vegetation in altered gravel-bed rivers can differ substantially from near-equilibrium river systems. In the Piave River there is a lack of a clear transition of younger to older communities from lower to higher morphological units, which reflects its complex history of channel adjustments. Also, islands are mainly generated from pioneering areas within the active channel width, and persist for less than 20 years.

Overall, a better understanding of how vegetation reacts to natural and anthropogenic impacts is needed in order to increase our ability to predict the response of river systems to flood events, and to assess the human impacts on river dynamics due to different management strategies of riparian vegetation and river restoration schemes. Moreover, the need for such improved understanding is also enhanced by a requirement to better predict river system and ecological habitat response to environmental change, notably climate and land use alterations.

Parallel to the substantial active channel narrowing and incision occurred during most of the twentieth century, the proportion of the fluvial corridor covered by vegetation at the channel margins has experienced a significant increase. These extensive mature riparian areas within the fluvial corridor have beneficial effects on the overall ecological potential of the area, and are in fact sometimes protected. However, these forested areas lie on former active channel portion of the river corridor and their protection could hamper efforts directed at promoting river restoration through channel expansion and aggradation. Furthermore, these areas could represent significant sources of drift wood if eroded and transported downstream during high-magnitude events. 


\section{Acknowledgements}

This research was founded by the University of Padova Strategic Research Project PRST08001, "GEORISKS, Geological, morphological and hydrological processes: monitoring, modelling and impact in the North-Eastern Italy", Research Unit STPD08RWBY-004, and by the CARIPARO "Linking geomorphological processes and vegetation dynamics in gravel-bed rivers" Research Project.

\section{References}

[1] Simon, A. and Collison, A.J.C. Quantifying the mechanical and hydrologic effects of riparian vegetation on streambank stability. Earth Surface Processes and Landforms, 2002, 27(5), 527-546.

[2] Van de Wiel M.J. and Darby S.E.. A new model to analyse the impact of woody riparian vegetation on the geotechnical stability of riverbanks, Earth Surface Processes and Landforms, 2007, 32, 2185-2198.

[3] Vitti P. Vegetazione e morfologia fluviale del Piave nel Vallone Bellunese (in Italian). MSc Thesis; University of Padova, 2010, pp. 117.

[4] Vitti P., Picco L., Mao L., Sitzia T., Comiti F., Rigon E. and M. A. Lenzi. Linking riparian forest structure and fluvio-morphological characteristics in a gravel bed river (Piave river-Italian Alps). Poster presented at the International Workshop Advances in River Science, 18-21 April 2011, Swansea, UK.

[5] Murray, A.B. and Paola, C. Modelling the effect of vegetation on channel pattern in bedload rivers, Earth Surface Processes and Landforms, 2003, 28, 131-143.

[6] Tal, M. and Paola, C. Dynamic single-thread channels maintained by the interaction of flow and vegetation, Geology, 2007, 35, 347-350.

[7] Hupp, C.R. and Osterkamp, W.R. Riparian vegetation and fluvial geomorphic processes, Geomorphology, 1996, 14, 277-295.

[8] Mao L., Comiti F., Andreoli A., Picco L., Lenzi M. A., Urciuolo A., Iturraspe R., Iroumé A. Role and management of in-channel wood in relation to floods events in Southern Andes basins. WIT Transactions on Engineering Sciences 60, 2008, pp. 207-216.

[9] Bathurst J. C., Crosta G. B., Garcìa-Ruiz J. M., Guzzetti F., Lenzi M. A. and Aragues S. R. DAMOCLES: Debris-fall assessment in mountain catchments for local end-users, International Conference on Debris Flow Hazards Mitigation: Mechanics, Prediction and Assessment, Proceedings 2, 2003, pp. 1073-1083.

[10] Bathurst J. C., Amezaga J., Cisneros F., Novillo M., Iroumé A., Lenzi M. A., Mintegui Aguirre J., Urciuolo A., 2010. Forests and floods in Latin America: Science, management, policy and the EPIC FORCE project. Water International 35, (2), 114-131. 
[11] Gurnell, A.M. and Petts, G.E. Island-dominated landscapes of large floodplain rivers, a European perspective, Freshwater Biology, 2002, 47, 581-600.

[12] Hupp, C.R. and Rinaldi, M. Riparian vegetation patterns in relation to fluvial landforms and channel evolution along selected rivers of Tuscany (Central Italy), Annals of the Association of American Geographers, 2007, 97(1), 12-30.

[13] Surian, N. and Rinaldi, M. Morphological response to river engineering and management in alluvial channels in Italy, Geomorphology, 2003, 50, 307326.

[14] Surian N., Ziliani L., Comiti F., Lenzi M. A. and L. Mao. Channel adjustments and alteration of sediment fluxes in gravel-bed rivers of northeastern Italy: Potentials and limitations for channel recovery. River Research and Applications 25 (5), 2009, pp. 551-567.

[15] Comiti, F., Da Canal, M., Surian, N., Mao, L., Picco, L. and Lenzi, M.A. Channel adjustments and vegetation cover dynamics in a large gravel bed river over the last 200 years, Geomorphology, 2011, 125, 147-159.

[16] Lenzi M. A., D’Agostino V., Gregoretti C., Sonda D. A simplified numerical model for debris-flow hazard assessment: DEFLIMO. International Conference on Debris Flow Hazards Mitigation: Mechanics, Prediction and Assessment, Proceedings 1, 2003, pp. 611-622.

[17] Lenzi M. A. Research developments in debris flow monitoring, modeling and hazard assessment in Italian mountain catchments. WIT Transactions on Ecology and the Environment 90, 2006, pp. 135-145.

[18] Rigon E., Comiti F., Mao L., Lenzi M. A. Relationships among basin area, sediment transport mechanisms and wood storage in mountain basins of the Dolomites (Italian Alps). WIT Transactions on Engineering Sciences 60, 2008, pp. 163-172.

[19] Conesa Garcìa C. and M. A. Lenzi (eds). Check dams, morphological adjustments and erosion control in torrential streams, Nova Science Publishers Inc., New York, 2010, pp. 339.

[20] Mao, L. and Surian, N. Observations on sediment mobility in a large gravel-bed river, Geomorphology, 2010, 114(3), 326-337.

[21] Osterkamp, W.R. and Hupp C.R. Geomorphic and vegetative characteristics along three Northern Virginia streams. Geological Society of America Bulletin, 1984, 95, 1093-1101.

[22] Tabacchi, E., Correll D.L., Hauer R., Pinay G., Planty-Tabacchi A.M. and Wissmar R.C. Development, maintenance and role of riparian vegetation in the river landscape, Freshwater Biology, 1998, 40, 497-516.

[23] Bendix, J. and Hupp, C.R. Hydrological and geomorphological impacts on riparian plant communities, Geomorphology, 2000, 14, 2977-2990.

[24] Picco L., Mao L., Rigon E., Moretto J., Ravazzolo D., Delai F. and M. A. Lenzi, 2012. Medium term fluvial island evolution in relation with flood events in the Piave River. (This volume, pp. 12).

[25] Gurnell, A.M., Petts, G.E., Hannah, D.M., Smith, B.P.G., Edwards, P.J., Kollmann, J., Ward, J.V. and Tockner, K. Riparian vegetation and island 
formation along the gravel-bed Fiume Tagliamento, Italy, Earth Surface Processes and Landforms, 2001, 26, 31-62.

[26] Zanoni, L., Gurnell, A., Drake N. and Surian, N. Island dynamics in a braided river from analysis of historical maps and air photographs, River Research and Applications, 2008, 24, 1141-1159. 